\title{
THEORETICAL AND METHODOLOGICAL TRENDS IN ENVIRONMENTAL
} EDUCATION RESEARCH

\author{
Paul Hart ${ }^{1}$ \\ Catherine Hart ${ }^{2}$ \\ Claudio Aguayo 3 \\ Flávia Torreão Thiemann ${ }^{4}$
}

\begin{abstract}
This paper is structured as a conversation among four researchers. In the first session, Paul Hart and Catherine Hart present a timely and carefully drawn reflection on the issue of current theoretical and methodological trends in environmental education research. In the second section Claudio Aguayo and Flávia Torreão Thiemann present some collaborative reflections on the issue that resulted from the World Café session conducted by them at the 13th Invitational Seminar on EER on Critical Environmental Education Research: Theoretical and Methodological Trends. In order to contextualize and introduce the seminar's theme, they also offer a brief history of Brazilian critical EER.
\end{abstract}

Keywords: Theoretical and methodological trends. Critical EER. World Café.

\section{TENDENCIAS TEÓRICAS Y METODOLÓGICAS EN LA INVESTIGACIÓN EN EDUCACIÓN AMBIENTAL}

\section{Resumen}

Este artículo está estructurado en la forma de una conversación entre cuatro investigadores. En la primera parte, Paul Hart y Catherine Hart presentan una reflexión, cuidadosa y pertinente, sobre el tema de las actuales tendencias teórico-metodológicas en la investigación en educación ambiental. En la segunda parte, Claudio Aguayo y Flávia Torre Thiemann presentan algunas reflexiones colectivas sobre el tema, que resultaron de la sesión de World Coffee, conducida por ambos durante el 13th Invitational Seminar, en el EER on Critical Environmental Education Research: Theoretical and Methodological Trends. Con el objetivo de contextualizar e introducir el tema del seminario, ambos ofrecen, además, una breve historia de la investigación en educación ambiental crítica en Brasil.

Palabras clave: Tendencias teóricas y metodológicas. Investigación Crítica en Educación Ambiental. Café con Letras.

\footnotetext{
${ }^{1}$ Ph.D. Faculty of Education, University of Regina. Regina, Canada.paul.hart@uregina.ca

${ }^{2}$ Ph.D. Faculty of Education, University of Regina. Regina, Canada. catherine.hart@uregina.ca

${ }^{3}$ Ph.D. Senior Researcher, Centre for Learning and Teaching, Auckland University of Technology. Auckland, New

Zealand. claudio.aguayo@aut.ac.nz

${ }^{4}$ Senior Researcher, Fubá Educação Ambiental e Criatividade LTDA. São Carlos, Brazil. 


\title{
TENDÊNCIAS TEÓRICAS E METODOLÓGICAS NA PESQUISA EM EDUCAÇÃO AMBIENTAL
}

\begin{abstract}
Resumo
Este artigo está estruturado na forma de uma conversa entre quatro pesquisadores. Na primeira parte, Paul Hart e Catherine Hart apresentam uma reflexão, cuidadosa e pertinente, sobre o tema das atuais tendências teórico-metodológicas na pesquisa em educação ambiental. Na segunda parte, Claudio Aguayo e Flávia Torreão Thiemann apresentam algumas reflexões coletivas sobre o tema, que resultaram da sessão de World Café, conduzida por ambos durante o 13th Invitational Seminar, no EER on Critical Environmental Education Research: Theoretical and Methodological Trends. Com o objetivo de contextualizar e introduzir o tema do seminário, ambos oferecem, ainda, uma breve história da pesquisa em educação ambiental crítica no Brasil.
\end{abstract}

Palavras-chave: Tendências teóricas e metodológicas. Pesquisa Crítica em Educação Ambiental. Café com Letras.

\section{Theoretical and methodological trends in environmental education research: Paul Hart and Catherine Hart}

\section{Introduction}

Within the context of a workshop on theoretical and methodological trends in social and educational research at the 13th International Seminar on Environmental Education Research in Brazil, Hart (2015) challenged participants, as critical environmental education (EE) researchers, to explore and engage emergent theories and methodologies. The challenge evolved both from within EE research (e.g., Environmental Education Research, Special Issue, 2005) and from social and educational research in journals such as Qualitative Inquiry, International Journal of Qualitative Studies in Education, and Reconceptualizing Educational Research Methodology. Scholars, notably critical feminist and new materialist, compel educational researchers to problematize methodological simplicity (CHILDERS, 2012; KORO-LJUNGBERG; MAZZEI, 2012) and to reconceptualize qualitative research by engaging qualitative theory at levels of epistemological and ontological groundings.

At the Brazilian seminar, conditions were created for challenging thinking amongst EE researchers concerning the adequacy of contemporary social theory and of traditional qualitative research applications in addressing a widespread disregard for nonhuman nature (ALAIMO, 2010). The idea was to actively engage the need to move beyond traditional qualitative approaches, now plagued by critiques of naïve interpretivism, representation and legitimation. The challenge was to make sense of the rapid evolution of ideas and complexities of new theories and concepts driving change. At stake, says McCoy (2012), is more than the knowledge we make as researchers, but worlds we make, the kinds of people we want to be and the kind of work we need to do in the world.

\section{What's Going on Here?}

There are many ways to engage new theory-praxis movements and each involves reading/study (LEWIS, 2017) and what St. Pierre (2002) calls "getting free" of one's self, that is, 
getting beyond the assumptions, rooted in traditional research discourses, that drive our thinking about what counts as inquiry. Jackson and Mazzei (2012) characterize this as "thinking with theory" within, against and beyond one's experience. Within the provocation to seminar participants, this work amounts to re-positioning oneself as a researcher-differently than the rather unfair perception assigned to militant critical researchers who are often dismissed as radicals. It was no coincidence then that MacLure (2011) asked "Where are the ruins?" in a paper that interrogated "ruins" as a way of opening up questions about what happens when researchers attend to the embodiment of language in new materialist research, perhaps as another approach, perhaps as a kind of postcritical scholarship and action.

Arguably, feminist EE researchers have moved environment in education beyond the linguistic turn of post-informed structuralisms and modernisms in education, and beyond issues of identity/agency as self-centred and humanist. Working these ruins for St. Pierre and Pillow (2000) opened doors for different thinking, conceptualized as new postqualitative and posthumanist terrain for disrupting and reconceptualizing educational research (see also Brown, Carducci \& Kuby, 2014; Koro-Ljungberg, 2016). And while it has been hard to escape traditional assumptions of interpretive mastery, narrative coherence and the presumptions of representing "others," working the ruins has become a methodological project of change - an escape from existing dominant discourses of research. Post qualitative inquiry engages new forms of relationality, responsibility/reflexivity, decentred researchers selves, partial knowledges, uncertainties, holistic first person accounts, sustained engagements, entanglements and diffractions. As Dillard (2006) says, when the music changes, so must the dance. Educational research has evolved beyond reductionist accounts to materially engage embodied knowledge and affective intensities that move and connect bodies beyond human interpretation, beyond constitutive forces of discourse and culture to re-engage matter and nature. So must EE research.

\section{What's Wrong with What's Going on Here?}

By foregrounding discussions on diversity within qualitative research as seminar starters, EE scholars were invited to deepen dialogue about diverse theory-into-method issues in ways that foreshadow future seminar experiences. Theory, in the recent proliferation of social and educational research, has been reconceptualized as assemblages of interrelated concepts that can enrich our thinking about research processes and think through how we "do" theory. Implications include rethinking research questions and methods in terms of the kinds of evidence required to explore the complexities of change across levels of thinking from worldview to specific issues of everyday life. For example, Jones (2010) in Qualitative Inquiry generates theoretical vantage points that create conceptual openings for possibilities of thinking "differently" and for creating "becoming spaces" where thinking and doing may be less conflicted. This work aligns with a recent "posthuman turn" in educational research involving both ontological and epistemological revision as well as intersectionalities that foreground changes in methodologies and methods. What recent theoretical movements across several perspectives seem to foreshadow are necessary destabilizations of dominant discourses of social and educational thought as well as new groundings for educational and EE inquiry.

What was intended for the research seminar in Brazil was to create conditions for getting lost in the aporias of research, "in paradoxes that trouble" beyond the hubris of perpetual mastery, by diverting ourselves from this course. Following Lather's $(2006,2007)$ ideas of destabilizing notions of "progress," normativity or certainty, we must disrupt the linear sense of research 
development towards consensus or "the right way" (see LEWIS, 2017). We can employ mapping to help us "get lost" in studying the field of EE research as a means of exploring what more our research in EE can do in the sense of research opened up and sustained by diversity (LEWIS, 2017). While some deconstructive un-learning is implicated as an engine for critical selfreflection, future research seminars may be experienced as opportunities to stumble over the potentialities of our inquiries to ask any kind of research question at all and to challenge our capacities to debate the intents and warrants of diverse sets of possibility.

What follows then is our attempt to map some possibilities as conceptual openings for thinking differently, as Jones (2010) says, to engage in "becoming spaces" that post-critically move us from onto-epistemic positions of resistance to "wanting" to explore diverse ways of knowing and their applications in methodologies and methods. Of course, questions of whether researchers within neoliberal-based postsecondary institutions have time and space to read theory and methodology-related theory-into-praxis remain. We believe that failure to do so for EE researchers could mean that EE-based literature lags behind and thus lacks congruity with current thought on onto-epistemic groundings for approaches to methodologies and methods, as currently re-framed by different discourses of social/educational inquiry.

\section{Where Are We Going?}

So, what might it look like to explore beyond the conceptual limits of contemporary qualitative inquiry within education and EE? We might turn to post-qualitative research which encourages applications of new theoretical ideas, concepts and methods beyond what St. Pierre (2011) designated as conventional humanistic qualitative method. What follows is one portrayal of qualitative inquiry that highlights possible paths of becoming beyond images of coherent, stable subject and already existing knowledge. Each path creates openings for different ways of thinking and creating knowledge where ontology and epistemology are intertwined.

A partial mapping of this landscape may be visualized as a way of accessing lines of flight beyond existing established territories of qualitative research. Such de-territorializations provide spaces to question existing conventions as openings for discussions at future EE seminars. There are many examples of such movements. Johansson (2016), for example, describes how she moved from a traditional qualitative researcher's established strategy (focus group interviews) by following its anthropocentric rules and structures (giving preference to epistemological questions) to post-qualitative methodologies that re-invite ontological questions into research, thus signifying a connection between learning and becoming and change (Lenz Taguchi, 2010). In this case the assumption of an ontology of imminence highlighted the impossibility of separating learning from changing one's being, that is, from becoming (as changed), as well as the impossibility of dualisms between human and nonhuman.

As theory evolves at onto-epistemic levels, and as new concepts for engaging methodologies and methods follow this movement to challenge traditional qualitative applications, conditions are created for reconceptualizing qualitative research. Over the last three decades, the educational research community has persisted in recalibrating their theoretical and methodological positions, thus disrupting dominant research discourses. Thinking through a politics of inquiry beyond subjects, or for non-representational methodologies, or for greening postcolonialism "become" new ways of imagining nature and humanity's relations to it. There are now many entry points for EE researchers to make the complex transitions of research processes more visible and accessible. However, EE researchers must convince themselves that it 
has become crucial to so engage. One entry point is to begin theoretically with onto-epistemic awareness, with methodologically informed ambiguity, as Johansson (2016) does above. However, we could also choose to follow actual research practices through somewhat historical currents in the movement from poststructuralist-informed inquiry to new materialist or relational materialist approaches. Both approaches could acknowledge onto-epistemic awareness as a crucial part of all qualitative inquiry. Each implicates theoretical perspectives informing each level of inquiry (from theory to practice).

In problematizing methodological simplicity and opening to practice-grounded theoretical complexity, we are in fact working at changing social imaginaries, moving EE research beyond some invisible boundaries concerning what can count for inquiry. We are working to disrupt boundaries - humanist, empiricist, constructivist and critical-poststructuralist - and to engage in reconstructing EE researchers' own conceptualizations of inquiry, their positionings in respect of their research. EE researchers may choose to think against and beyond concepts drawn from current educational research activity as disparate theory-into-methods choices in support of diverse onto-epistemic and methodological approaches. With these ideas in mind we suggest several possibilities of engagement, as pathways or flightlines or spaces where knowledges, methods and transparency become more explicit.

\section{Oh! The Places You'll Go...}

Given complex changes in postqualitative methodology and methods, there is no easy way into the literature, although there are many directional implications and decision points for educational and EE research. For example, Myra Hird (2009) described working with concepts such as "Transcorporeality. Entanglement. Meeting-With. Matter. Nonhuman. Causality. Intraaction. Disclosure." She was writing to distinguish material feminisms through the provocations that these conceptual perspectives provided. Much like the idea of "provoking," intended to characterize the Brazilian Research Seminar, this paper's interest was to engage new possibilities for EE research. Hird (2009) argues against modernism's claim to "objective" access to the natural world as well as postmodernism's claim that what we call real has its reality only in language. Instead, using Barad's (2007) new materialism, she explores the use of new concepts that bridge culture-nature as intra-actions that bring the two together as natures/cultures. In effect, this EE-sensitive argument is about considering "word" and "thing" (mind-body) as ontologically entangled within an agential realism about real consequences rather than representations.

Seen in this light, educational research and EE research are tending toward present/perform/engage rather than merely "represent" phenomena. New methodological orientations tend to ground as new empiricisms, new feminist materialisms and posthumanisms, following Alaimo and Heckman (2008), Bennett (2010) and Coole and Frost (2010) who theorize the co-constitutedness of cultural discourse and materiality (Lenz Taguchi, 2013). The idea is that if matter itself is conceptualized as agentic, then all sorts of bodies, not just human bodies, are recognized as having agency. Ontologically, the "new" orientation decenters humanism and reengages nonhumans, other-than-humans and more-than-humans (Braidiotti, 2013) with particular onto-epistemic implications that is, in not simply researching (in the world) without "feeling" it and doing something about it.

\section{So What?}


What if EE researchers could seriously explore materialist experiences of embodiment in nature from both materialist and discursive framings? Embodied involvement differs from a bird's eye view of inquiry in its own messy, implicated, connected involvement as researchers in knowledge production (what Barad [2007] calls onto-epistemology). New feminist materialism foregrounds a new ethics as engaged praxis that displaces objectivity as a central value in social and educational research. Such an ethico-onto-epistemological emphasis in new material feminisms, on "becoming-in-relation," has potential to instantiate an ethics of care through an ecological grounding in respect and responsibility for the vitality of all matter (Barad, 2007).

What if the research emphasis shifts from social construction to social production (Coole \& Frost, 2010), from questions of "caring" to deeper questions of "affect," to questions of how desires, feelings and meanings contribute to social and educational research. The focus now shifts to questions of relational networks or assemblages of animate and inanimate "affect." The intention of new materialist ontology is to transcend the culture-nature divide through new conceptual and methodological frames for EE research. The multi-dimensional nature of conceptual and methodological challenges then trickles down to researchers' questions about how research could or should be conducted. And while new forms of inquiry proliferate in social and educational research, their potential for strengthening EE research remains.

What if special issues of educational and social research journals already reflect these changes? For example, Lisa Mazzei (2013) describes what it is like to rethink material-discursive relations, that is, how agency, analysis and language still matter when relationships are mutually constituted in new materialist approaches in the production of knowing and becoming. Her purpose was not merely to illustrate how methodological practices of reading data "with and through" a materialist lens opens up new ways of seeing and thinking but how such practices actually produce different encounters with data, research settings and participants. MacLure (2011) describes such an expanded sense of inquiry as more attentive to material engagements with an infra-empirical embodied sense of affect, that is, affects as sensations, forces and movements (beneath the skin) of both participants and researchers. Is there potential for both researchers and participants to be transformed in acts of mutual becoming? Perhaps? But at ontoepistemic levels?

What if rethinking inquiry at one level of inquiry requires rethinking at all levels from theory to fieldwork methods? Unpacking new concepts at each level, concepts such as affect and assemblage, that replace older notions of human agency and social structure, is complex. For example, a key concept in new materialist ontology involves considering research in terms of assemblages of relations (at macro and micro levels). "Affect" replaces human agency as a becoming that reflects changing capacities within territories where lives unfold (see Thrift, 2004). As the language shifts, the focus shifts from determining normative social (i.e., power) structures to finding capacities for reterritorializing existing boundaries.

\section{Implications-A Sampling of New Methods}

This kind of thinking (with theory) opens up possibilities for an entire suite of conceptual groundings for new methodological approaches. For example, Mazzei (2013) maps a methodological approach that draws diffractively from feminist, critical race, postcolonial and poststructural theories. Think of Barad's (2007) concept of intra-action, Grosz's (2010) concept of freedom and Kirby's (2011) concept of earth's grammar, to construct diffractive strategies of reading data with each of these theoretical concepts. Think of diffractive analysis that attends to 
complexities of, for example, researching "dance" as agential and relational (Hickey-Moody, Palmer \& Sayers, 2016).

From a posthumanist perspective, diffractive strategies distribute notions of agency/identity beyond humanist agents to a complex entangled network of human and nonhuman conditions that can intra-act with our predispositions to change the world. In a diffractive reading, environment is not produced by or for humans. For example, Nancy Tuana (2008) described a kind of "viscous porosity" within agential realist interactions between humans and environment (see also, SOMERVILLE, 2016) during extreme weather events. Juelskjaer (2013) has explored gendered relations of space-time-matter by reading poststructural feminist theorizing, agential realism and empirical material diffractively. And Taylor and Ivinson (2013) view post-qualitative research in terms of new methodological orientations that some refer to as "new empiricisms." Each of these researchers draws on the work of Barad (2007), Alaimo and Hekman (2008), Bennett (2010) and Coole and Frost (2010). Each reminds us that, as in traditional Maori thought, the human-natural world is an entangled continuity and that the subject-object split in the binary is in fact a western ontological problem exported via colonialism (see Jones \& Kawehau-Hoskins, 2013).

\section{Bringing EE Back into Educational Discourse-Blatantly Privileging Posthumanist-Based Inquiry}

EE researchers may also relate to post-human dimensions of new materialist theory where matter is considered as agentic beyond human bodies. In acknowledging that all sorts of bodies have agency in human subjectification and meaning making, decentering the human signifies an ontological shift where humans accept greater responsibility for "our" environments. "Caring for the earth" works beyond relational epistemology, beyond the slogan, to account for other forces, affective capacities and energies that permit humans to see differently, and perhaps diffractively, and to become more deeply connected through the affective power of things. As researchers we can begin to focus on how we are deeply implicated through our work - as messy, complex and embodied-ontologically and epistemologically within an ethics that displaces objectivity as a central value in our studies. The ecological dictum that "everything is indeed connectedontologically and epistemologically - to everything else" marks a sea-change - an ontological change that speaks back to what Taylor and Ivinson (2013) refer to as the second "corporeal" turn in social theory (EVANS; RICH; DAVIES, 2009; SHILLING, 2008).

Onto-epistemic work in material feminisms also implicates what and who comes to matter as well as how things matter differently, and how things may be explored using various sociomaterial assemblages (see FENWICK; EDWARDS, SAWCHUK, 2011). For example, in order to move beyond earlier notions of participation and communities of practice, socio-eco-material approaches such as $\left.\left.\mathrm{ANT}^{5}\right], \mathrm{CHAT}^{6}\right]$, complexity theory and socio-spatial theories offer resources to intra-actively explore ways that learning and knowing are rooted in action (and in action research) in order to expand educational processes of pedagogy. Socio-material studies shift the focus beyond personal-social to challenge more complex posthuman hierarchies reconceived as assemblages (of, for example, out-of-classroom events) that may reveal patterns, forces, or capacities within complex in-and-out-of-school pedagogical encounters.

\footnotetext{
${ }^{5}$ Actor (or Actant) Network Theory - or, as Latour says, Actant Rhizome Theory (ART) (see Crawford [1993])

${ }^{6}$ Cultural Historical Activity Theory - in Engström's (2001) work - in many ways advances Participatory Action Research
} 
Whereas earlier empiricist notions of positivist methods reduced interpretivism in action research to factors or themes or patterns, socio-material approaches use interactional engagement, as a kind of awareness to engage participants at levels beyond solving an issue or problem, to explore internal (ontological) conditions of possibility for the existence of the problem in the first place (i.e., the culture constraints of dominant discourses). Reconceived as new empiricisms, social and environmental problems are viewed as worthy of more complex challenges for researchers and participants together to "get free of themselves" because it is a self, that has already integrated into social norms and discourses, that socially engaged forms of inquiry really need to engage. This complex social play connects with ideas of nomadism or highly creative or speculative play taking place in rhizomatic forms that can schizophrenize pre-existent taken-forgranteds as certainties (for example, the transgendered person who feels compelled to perform differently depending on circumstances). And while this conceptualization of complexities and spacialities may suggest ontologies both realist and relational, they are no longer simplistically researched as being about only personal (or humanist) conceptions of "self."

As Gale (2014) says, the shift in thinking with these new concepts is ontological in the first place where "being" is less personal if reconceptualized as "becoming" because individual concerns like "illness" or "place" have nonpersonal individuality. They are haecceities with more than personal ramifications. This is the secret of new empiricisms, and postqualitative inquiries as radical forms of nonpersonal individuation (beyond anthropomorphism) that move binaries toward multiplicities and deterritorialization (GALE, 2014). Applied to activist-participatory notions, action research now involves re-working pedagogy, as for example, within speculative realist fictions or other speculative forms where taken-for-granted discursive familiarities are made strange. These speculative realist approaches to inquiry acknowledge possibilities of revitalization places where ambiguities are happily tolerated as transgressive pedagogies but also as transgressive research.

It is exciting to have focused the 13th Seminar as an opening to diverse ways of foregrounding the rather dramatic evolution of thinking and practice within educational research. We are just beginning in Brazil to see a transversality that does not privilege culture but focuses on what Donna Haraway (2003) calls "nature cultures." This movement will not lead to a unified theory or methodological stance but, as has been touched upon above, begins to provide theoretical sensibilities and groundings for provocation for researchers to break through transcendentalist and humanist traditions beyond postmodernisms in ways that move towards very different natural assemblages (e.g., abstract machines) and embodied subjectivities. In particular, at this junction of the Anthropocene which Braidotti (2000) referred to as the posthuman predicament, bringing nature to culture entails a qualitative shift away from reductive dualist thought in general and toward stronger deterritorializations of EE research. As Val Plumwood (2007) put it, survival of our species depends on how our relationships are reconfigured. At this moment in time, working with new posthuman and post-qualitative strategies of inquiry seems crucial in rethinking our mode of humanity. So, in this seminar in Brazil we turned our attention to embodiment, affect, connectivities and communications at research seminars which might have the potential to open possibilities for deeper entanglements with the planet.

\section{The $13^{\text {th }}$ Invitational Seminar on EER: Claudio Aguayo and Flávia Torreão Thiemann}


The above "provocation" leading to the $13^{\text {th }}$ Invitational Seminar on EER challenged participants to reflect on the adequacy of current social and educational theories. It provided the grounds to consider matters of doing environmental education research within an un-constructed onto-epistemic awareness going beyond traditional qualitative approaches, and moving towards embodied subjectiveness of culture-nature assemblages in "becoming" and affecting our work as educational researchers. This was only one of the five main fields of inquiry that were presented to the participants. As the $13^{\text {th }}$ Invitational Seminar on EER started to be conceived by the organizing group it became quite clear that amidst all the current and new theoretical and methodological trends in environmental education research, which bears a richness that can be attained in the provocation from the first section of this paper, critical EER was worthy of a deeper examination. The choice was influenced by the fact that the seminar would take place in Brazil, a country with a strong grounding in critical theory, and thus, critical EER. In this second section of the paper we present a brief history of critical EER in Brazil, aimed at contextualizing the choice of the seminar's main theme, followed by a report of how the issue of theoretical and methodological trends was teased and developed among participants during a World Café session at the seminar, while seeking to think and reflect around the original provocation.

\section{Origins and evolution of critical EER in the Brazilian context}

Environmental education in Brazil has been shaped by social movements and privileges as a more critical aspect, having been born within the countercultural movements of the 1960's and consolidated in the 1980's during a period of social and political change in the country (CARVALHO, 2002). It began linked to movements of popular education, with Paulo Freire as one of its key references, and is present in diverse projects across communities and related to social movements and issues (OLIVEIRA, 2008). Paulo Freire's work on generative themes, which must necessarily be understood from the relations between people and their reality (FREIRE, 2005), underpins education in the local context and in the groups that participate in it, and is dear to critical environmental education in the country.

The critical orientation of Brazilian environmental education (EE), although not the only EE perspective in use within it, makes it unlike many kinds of environmental education existing in several other countries (CARVALHO, 2002). In Brazil, Carvalho (2001) has traced the process of constitution of Brazilian environmental educators, and the field of environmental education itself, as being created from a confluence between their lives and historical events, such as the international conferences that took place in the 1970's and 1990's, for example: the Intergovernmental Conference on Environmental Education (Tbilisi, 1977); and the United Nations Conference on Environment and Development (UNCED) (Rio de Janeiro, 1992). It is in this process that an early bias towards nature conservation and preservation gave way to a more critical perspective (LOUREIRO, 2006).

This movement mirrors what happened outside the country. According to Sauvé (1999), in the 1970's environmental education was transformed from conservation education in the 50's and 60's, to seeing the environment as a problem, when realizing the magnitude of the environmental problems. Even so, at that time the tendency remained an education focused on personal experiences of the environment as nature. For us, it is during the 80's and 90's that the contribution of critical theory (revisited in the light of constructive postmodern thinking, which believes in the possibility of transformation and change) to environmental education enabled its 
consolidation to the critical EER fingerprint which Brazilian EE is known and recognised for today.

If, in Brazil, the field of environmental education has been consolidated from its practice, as shown by Carvalho (2001), research in EE is closely linked to the post-graduation system, since most of the research is developed at universities through postgraduate programs (CARVALHO; TOMAZELLO; OLIVEIRA, 2009). However, as for the theoretical and methodological underpinnings of both EE practice and research, Carvalho (2001), and Freitas and Oliveira (2006), indicate a lack of structure in the methodological aspects of both. In EE research, Freitas and Oliveira (2006) tracked methodological tendencies in EER presented at the first EPEA [Encontro Pesquisa em Educação Ambiental[ $\left.{ }^{7}\right]$ ], the national EER meeting, which occurred in Brazil in July, 2001. These authors identified what they considered an anomaly regarding the constitution of the research field, and speculated that this could be linked to the fact that most researchers came from the Natural Sciences field. When moving into Education, they revealed "the fragility in the approach of themes situated at the border/interface between these two large knowledge [science/education] areas" (FREITAS; OLIVEIRA, 2006, p.185). As for the diversity of EER approaches, most of these fell under the realm of critical approaches (CAVALARI; SANTANA; CARVALHO, 2006).

In recent years, Brazilian EER has been reviewed by different groups based on the papers presented at the major national conferences, for example by Kawasaki et al. (2009), Catalão (2009) and Avanzi, Carvalho and Ferraro Júnior (2009). Looking into the papers presented at four EPEA, Kawasaki et al. (2009) encountered a growing emphasis on the theoretical and methodological groundings of EE, which the authors considered a move towards a better definition of which constitutes research in the field of EE in the Brazilian context. In addition, Catalão (2009, p.143), looking at five meetings of the EE working group of ANPed (the Brazilian National Association of Post-Graduation and Educational Research) found a critical identity in Brazilian EER, which the author attributed to a dialogue "between the complexity inherent to the educational process itself and the complexity of the socio-environmental field". Finally, Avanzi, Carvalho and Ferraro Júnior (2009) also found a predominance of the critical/emancipatory approach in papers presented at the ANPPAS (the Brazilian National Association of Research and Post-Graduation in Environment and Society) meetings from 2006 and 2008. Although the critical/emancipatory approach predominated, a broad overlook pointed to a multifaceted field, where diverse themes and theoretical underpinnings co-exist, adding to an effort to "construe articulations among knowledge fields such as ecology, politics and environment" (AVANZI; CARVALHO; FERRARO JÚNIOR, 2009, p. 91).

More recently, looking into environmental education research in Latin America, González-Gaudiano and Lorenzetti (2013) also recognized a "critical-transformative thinking style" in Brazilian research, although the authors considered that, due to the influence of science education specialists or of an instrumental vision of environmental education, "empiricist and positivist discourse and viewpoints are still dominant" in the region (p.176). The authors called for a debate that "would therefore serve to challenge the empirical-analytical tradition that is embedded in our research conceptions and practices, and make it possible to get the most out of theoretical and methodological approaches that improve the quality of different ways and genres of knowing" (GONZÁLEZ-GAUDIANO; LORENZETTI, 2013, p.176).

\footnotetext{
${ }^{7}$ EPEA is held every two years. The meeting is focused on EE research and theory.
} 
Environmental education research today presents itself as a field where many diverse research lines co-exist across countries and regional traditions. Methodological perspectives range from positivist research, emphasizing empirical, measurable and generalized data, to critical, participatory and post-interpretative perspectives (HART, 2013). According to Hart (2013), "if knowledge of human social affairs is socially construed and therefore somewhat relative to people and context, then there are philosophical grounds for diverse approaches and their implications in particular methods" (p. 507).

Faced with the diversity of theoretical and methodological approaches available to the environmental education researcher, Dillon and Wals (2008) suggested that the research questions should guide the choice of approach, and point to the importance of making explicit the paths chosen and the presentation of justification for those choices. We recognise that this process is uniquely dependent on the social and cultural particularities of the context where EE research is understood, and thus, developed. For example, speaking from a South-African context, O'Donoghue (2017, in this issue) talks about how each of the "interacting trajectories informing our work in southern Africa is examined for how these came to emerge within antecedent conditions that shaped the models of process towards change-orientated learning that we have come to work with in environmental education today", and how "early critical education discourses began influencing environmental education in the 1980s and proliferated in the early 1990s before briefly receding to become more prominent again in postcolonial trajectories that have come to the fore in recent years".

Leading up to the seminar, we had a "provocation" from the theme convenor to reflect on the proposed theme of "Critical Environmental Education Research: Theoretical and Methodological Trends", a challenging proposal. We decided to provide a setting that allowed for a free flow of ideas, with no intention of reaching a conclusion or closing the issue, but to open the discussion through reflection. We present below a brief description of the process and outcomes of the discussions held. Although five different seminar sub-themes were discussed at the session, we will focus only on the theme of this paper, theoretical and methodological trends.

\section{The World Café in critical EER}

As we gathered together in the first full day of work at the seminar, the main theme of critical EER was explored in five sub-themes. Critical Environmental Education Research: Theoretical and Methodological Trends" was discussed, as were the other four, at a "World Café" setting held early during the seminar. The methodology was adapted from http://www.theworldcafe.com. The intention of the world café is to foster an open exchange of ideas. In our case, the café aimed to provide ideas that could help the discussion of the seminar's sub-themes in the subsequent sessions.

All participants met at the EE Center at the venue in Bertioga, Brazil, where the $13^{\text {th }}$ EER Invitational Seminar was held, where five "tables" were set up, with small groups seated in a circle. Each group had a host, who was tasked with conducting the discussions at the table and reporting the conversations back to her/his group. Five short sessions were held, each one lasting 10-15 minutes only. In each one, participants could choose a table and use the session to develop the suggested questions/discussion topics working individually and/or in group collaboration. We made sure everybody went to every table, in order to give their contribution to all groups. We also organized people so that they did not move as a group, but mingled with the others, so they could converse with more people, and for enabling more diverse table discussions. 
The host for each table was responsible for welcoming the guests, providing a short introduction on the table's topic background, encouraging people to talk, and writing or drawing their ideas on the paper that covered the table. The host was also responsible for holding the memory of that table's discussion, and briefly presenting that to the new arrivals and sharing the main ideas and points from the previous round/s. All participants could also bring their ideas from the previous round/s, helping to seed the discussions with new takes on the topics. At the end of the café, each host made a short presentation of that table's insights, and later on helped the sub-theme's leader to prepare the next session.

We also set up a support team which helped organize the café, guiding people to the new tables, helping with the schedule, making sure there was a good mix of Brazilian and international participants in each table, keeping track of the time, and reminding people to write down/document the conversation. The team moved freely around the tables, sitting down when desired at a table, but also keeping track of the whole group. The same set of questions was presented at each new round to the fresh arrivals, but were addressed against previous discussion/s occurred at each table.

As the world café was designed to be the seminar's first working session, we wanted to use it to gather fresh perspectives on the proposed themes. So, we prepared only one general question: "What would you like to see discussed/ what questions do you propose/raise regarding the sub-theme....". The tables were set up around one of the following themes:

Sub-Theme 1: The Constitution of the EE Field

Sub-Theme 2: Researcher Training Policies

Sub-Theme 3: Critical Environmental Education Research: Theoretical and Methodological Trends

Sub-Theme 4: Aesthetics, Ethics, Politics

Sub-Theme 5: Language and Discourse

\section{Sub-Theme 3 World Café Outcomes}

Following the recording of the array of discussions and perspectives that emerged around "Sub-Theme 3: Critical Environmental Education Research: Theoretical and Methodological Trends", here we present some key outcomes from the discussion in this sub-theme. Figure 1 below shows the sequential flow of the collaborative coming together of ideas at that sub-theme table.

Given the characteristics of the World Café process, i.e. a collaborative array of ideas and discussions that emerged from and between participants themselves, as authors of this section of the article we have limited ourselves to only a first level thematic analysis of these ideas, with a focus on providing a descriptive analysis, as a further and deeper thematic account, such as inferential interpretations, would be beyond the scope of the original meanings provided from each and all participants. Therefore, the collection of ideas from this collaborative session of the seminar, initially recorded on paper and then translated into the flow diagram from Figure 1, is only a reflection of the nature of those conversations. However, they represent the spirit of the discussions. 
Discussion flow on theoretical and methodological trends in EER at the World Café

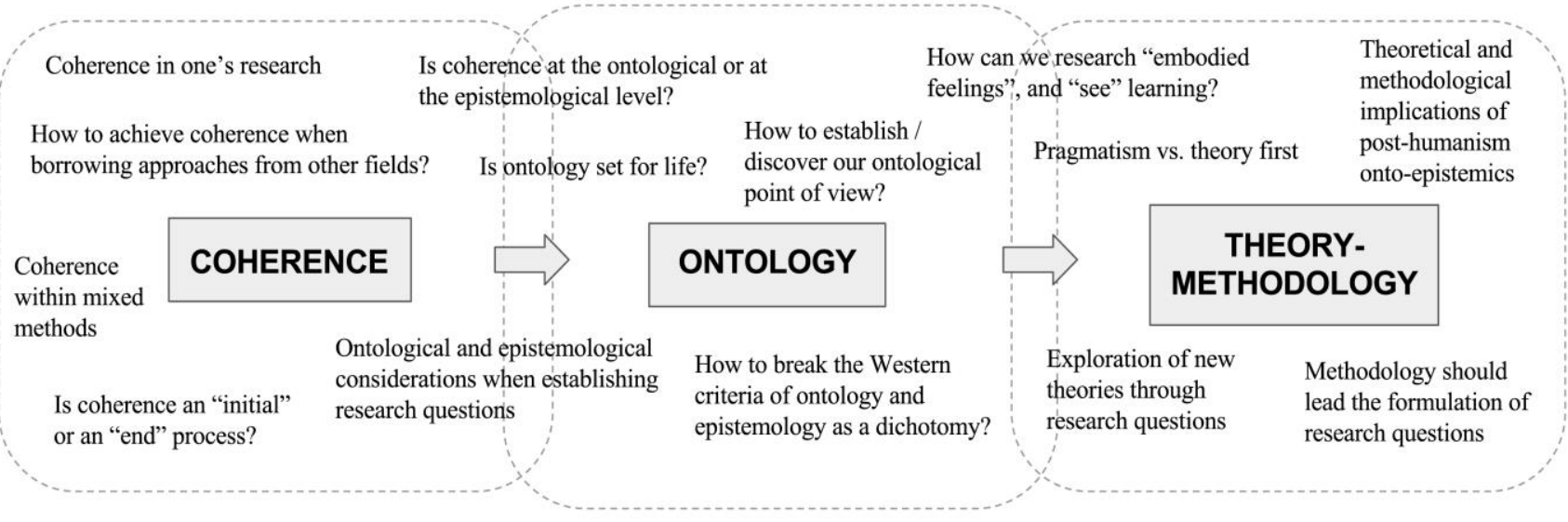

Figure 1. Flow diagram of the discussions at the World Café on theoretical and methodological trends in EER.

As shown in Figure 1, the discussions at the table started first around the concept of "coherence". Participant discussions addressed how maintaining coherence across the research process was important, not only in the formulation of research questions and research design, but also when borrowing theories and approaches from other related fields into environmental education research. Building up from coherence, discussions then shifted to the concept of "ontology" as a guiding philosophical start point when dealing with coherence. Participants discussed how important was to maintain coherence at the ontological and epistemological levels. They also discussed at what point, during the research process, ontology should be addressed, i.e. as an initial step and/or as an end result when formulating research. Discussions also touched on the influence on research of culturally situated ontological positions, in particular in relation to East/West and North/South cultural divides. Some thoughts were given to how researchers should establish, and (re)discover, their ontological positions, which led to considerations of the lifespan of ontological positions, i.e. "is ontology set for life?".

Following from the set of discussions and collective reflections initiated with the concept of "coherence", and then followed by the notions of "ontology" (and epistemology) as lead topics, group discussions then evolved into the theoretical and methodological implications of exploring and (re)discovering new "onto-epistemic awareness" in EER research. Questions of "pragmatism vs. theory first" were addressed, as well as methodological implications between "quantitative and qualitative" tensions between established versus emerging post-humanism and post-materialist educational research theories and methodologies. In relating back to the original provocation set out for this Word Café around theoretical and methodological trends in EER, one agreement that emerged from the discussions, and their reflections, was the acknowledgment of the unnecessary cultural dichotomy that exists between ontology and epistemology as separated elements. It was agreed by most, and embraced by some of the less experienced participants, the need to consider these as intertwined elements when formulating research, where the way we "see and embody" the world and "make sense of it" are inherently associated. This resonated with the initial provocation by Hart (2015) leading up to the seminar. Building up from that recognition, a sense of a need to reconsider one's "onto-epistemic awareness" flourished strongly 
in many participants, and was acknowledged as an accessible entry point, yet challenging strategy, to reconsider one's philosophical approach to EER.

\section{Closing reflections on theoretical and methodological trends in EER at the seminar}

An interesting array of discussions underpinning different philosophies and theoretical standpoints related to research in EE emerged from participants who contributed to the world café. The discussions held at the world café around theoretical and methodological trends in critical EER evolved from the notions of coherence and validity in doing research, to critical reflections around notions of ontology and its meaning within EER, to a final discussion and reflections on an entanglement of paradigms, theories and methodologies. One key outcome of the world café was a general call from participants to do EE research that is robust in coherence and validity. Either envisaging this from a 'disruption of boundaries' point of view, or from a yet more 'defensive' onto-epistemic of traditional qualitative research inquiry, a sense of agreement in the critical importance of doing research that is coherent emerged from the recollection of reflections and discussions held at the world café.

We also recognised willingness from participants to approach and explore the topic of theoretical and methodological trends in EER with an open-mind, which contributed to a collaborative collegiality in the pursuit of a reconceptualisation of qualitative research theory at ontological and epistemological levels. Participants, in this sense, provided a rich and diverse mapping of thinking differently with, and from, onto-epistemic reflections of doing research and being a researcher making knowledge that resides in the theoretical world we all nurture.

The session was not designed to lead to a deep discussion of the issue, but to open it up for further engagement in the future. This design probably prevented us from seeing many signs and indications of a 'coming together' between the intentions and expectations laid out from the original provocation from Hart (2015) permeating all the way from the literature to the world café session in Bertioga. At the session participants had the opportunity, at least for a brief moment, to engage in a social discussion with peers in EER, leading sometimes to a process of self-reflection and critical self-critique of our own onto-epistemological boundaries and nature in relation to our position within qualitative research praxis.

It remains to be seen what will be developed and permeate researchers' work from this point on so we can reflect on how this trends will influence the field both within Brazil and outside of it.

At this point, we would like to bring the reader's attention to some views from a group of 'emerging' scholars in EER from the Australasian context. Acknowledging that this is an almost anecdotal and tangential final reflection, it is interesting to note though how a group of emerging researchers in environmental education, self-denominated as \#aaeeer-australasian association of environmental education emerging researchers, that have indicated some degrees of disconformity with what has been described here as the "traditional" or "the right way' of doing research, somehow incarnate the calls from Hart (2015), and of the first section of this article, of exploring new ways of doing EE research.

In an attempt to address the main theme of the inaugural AAEE (Australian Association for Environmental Education) Research Symposium celebrated in Hobart in November 2014 'It's about dialogue and it's about time', and the open invitation to consider future research directions for environmental education, \#aaeeer presented a position paper to the Australian Journal of Environmental Education Special Issue on the inaugural research symposium targeting what they 
refer to a move to strive for bold, dangerous, and flourishing ways of doing EER (AGUAYO et al., 2016). This highly resonates with the provocation presented to participants of "SUB-THEME 3: Critical Environmental Education Research: Theoretical and Methodological Trends", as \#aaeeer provide a set of arguments for 'walking the talk' of reconceptualising established traditional trends in EER, with the intention to disrupt boundaries from diversity, and explicitly indicating new directions for EER, from an Australasian context, yet to be explored.

We find it interesting in a constructive manner to point this out here, and urge others to also engage in a critical reflection following the provocations and reflections presented here.

\section{References}

AGUAYO, C. et al. Perspectives From Emerging Researchers: What Next in EE/ SE Research? Australian Journal of Environmental Education, v. 32, p. 17-29, doi:10.1017/ aee.2015.57, 2016.

ALAIMO, S. Bodily natures: Science, environment and the material self. Bloomington: Indiana University Press, 2010.

ALAIMO, S.; HEKMAN, S. (Eds.). Material feminisms. Bloomington: Indiana University Press, 2008.

AVANZI, M.R.; CARVALHO, I.C.M.; FERRARO JR., L.A. Um olhar para a produção de pesquisa em educação ambiental a partir do GT ambiente, sociedade e educação, da ANPPAS. Pesquisa em Educação Ambiental, v.4, n.2, p.79-93, 2009.

BARAD, K. Meeting the university halfway: Quantum physics and the entanglement of matter and meaning. Durham: Duke University Press, 2007.

BENNETT, J. Vibrant matter: A political ecology of things. London: Duke University Press, 2010.

BRAIDOTTI, R. Teratologies. In BUCHANAN, I.; COLEBROOKE, C. (Eds.), Deleuze and feminist theory (pp.156--172). Edinburgh: Edinburgh University Press, 2000.

BRAIDOTTI, R. The posthuman. Cambridge: Polity Press, 2013.

BROWN, R.; CARDUCCI, R.; KUBY, C. Disrupting qualitative inquiry: Possibilities and tensions in educational research. New York: Peter Lang, 2014.

CARVALHO, I.C.M. A invenção do sujeito ecológico: sentidos e trajetórias em educação ambiental. 349 p. 2001. Tese (Doutorado em Educação) - Faculdade de Educação, Universidade Federal do Rio Grande do Sul, Porto Alegre, 2001.

CARVALHO, I. C. M. O 'ambiental' como valor substantivo: uma reflexão sobre a indentidade da educação ambiental. In: SAUVÉ, L. ORELLANA, I. SATO, M. Textos escolhidos em Educação Ambiental: de uma América à outra. Montreal, Publications ERE-UQAM, 2002, Tomo I, pp 85-90 (versão em português).

CARVAlHO, L.M.; TOMAZELlO, M.G.C.; OLIVEIRA, H.T. Pesquisa em educação ambiental: panorama da produção brasileira e alguns de seus dilemas. Cad. Cedes, Campinas, v.29, n.77, p.13-27, jan./abr. 2009. 
CATALÃO, V. Cenário temático da pesquisa em educação ambiental no contexto da ANPEd. Pesquisa em Educação Ambiental, v.4, n.2, p.135-145, 2009.

CAVALARI, R.M.F.; SANTANA, L.C.; CARVALHO, L.M. Concepções de educação e educação ambiental nos trabalhos do I EPEA. Pesquisa em Educação Ambiental, v.1, n.1, p.141-173, 2006.

CHILDERS, S. Against simplicity, against ethics: Analytics of disruption as quasi-methodology. Qualitative Inquiry, v. 18, n.9, p.752-761, 2012.

COOLE, D.; FROST, S. New materialisms: Ontology, agency, politics. Durham: Duke University Press, 2010.

CRAWFORD, T. An interview with Bruno Latour. Configurations, v.1, n.2, p. 247-268, 1993.

DILLARD, C. When the music changes, so should the dance: Cultural and spiritual considerations in paradigm 'proliferation.' International Journal of Qualitative Studies in Education, v.19, n.1, 59-76, 2006.

DILLON, J.; WALS, A.E.J. On the danger of blurring methods, methodologies and ideologies in environmental education research. In: REID, A.; SCOTT, W. Researching Education and the Environment - Retrospect and Prospect. New York: Routledge, 2008. p. 303-312.

ENGSTRÖM, Y. Expansive learning at work: Toward an activity theoretical reconceptualization. Journal of Education and Work, v. 14, n.1, p. 133-146, 2001.

EVANS, J.; RICH, E.; DAVIES, B. The body made flesh: Embodied learning and the corporeal device. British Journal of Sociology of education, v. 30, n.4, 389-391, 2009.

FENWICK, T.; EDWARDS, R.; SAWCHUK, P. Emerging approaches to educational research: Tracing the socio-material. London: Routledge, 2011.

FREIRE, P. Pedagogia do Oprimido. 49ª Reimpressão. Rio de Janeiro: Paz e Terra, 2005. 213 p.

FREITAS, D.; OLIVEIRA, H.T. Pesquisa em Educação Ambiental: um panorama de suas tendências metodológicas. Pesquisa em Educação Ambiental, v.1, n.1, p.175-191, 2006.

GALE, K. Action research and the assemblage: Engaging Deleuzian pedagogy and inquiry beyond the constraints of the individual and the group in education settings. International Journal of Qualitative Studies in Education, v. 27, n.5, p. 667-681, 2014.

GONZÁLEZ-GAUDIANO, E.; LORENZETTI, L. Trends, junctures, and disjunctures in Latin American environmental education research. In: STEVENSON, R.B. et al. International Handbook of Research on Environmental Education. New York and London: Routledge, 2013. p. 171-177.

GROSZ, E. Feminism, materialism, and freedom. In D. COOLE; S. FROST (Eds.), New materialisms: Ontology, agency, and politics, p. 139-157, 2010.

HARAWAY, D. The companion species manifesto: Dogs, people, and significant otherness. Chicago: Prickly Paradigm Press, 2003. 
Hart, P. Theoretical and methodological trends: Provocation. Unpublished, 2015.

HART, P. Preconceptions and Positionings - Can we see ourselves within our own terrain? In: STEVENSON, R.B. et al. International Handbook of Research on Environmental Education. New York and London: Routledge, 2013. p. 507-510.

HICKEY-MOODY, A.; PALMER, H.; SAYERS, E. Diffractive pedagogies: Dancing across new materialist imaginaries. Gender and Education, v. 28, n. 2, p. 213-229, 2016.

HIRD, M. Feminist engagements with matter. Feminist Studies, v. 3, n. 2, p. 329-346, 2009.

JACKSON, A.; MAZZEI, L. Thinking with theory in qualitative research: Viewing data across multiple perspectives. London: Routledge, 2012.

JOHANSSON, L. Post-qualitative line of flight and the confabulative conversation: A methodological ethnography. International Journal of Qualitative Studies in Education, v. 29, n.4, p. 445-466, 2016.

JONES, A.; KAWEHAU HOSKINS, T. Object lessons: Vital materiality and Indigenous settler engagement. Keynote presentation, Summer Institute in Qualitative Researcher, Manchester Metropolitan University, p. 22-26 July, 2013.

JONES, L. Reflexivity as a ground-clearing activity within the context of early years' pedagogy. Qualitative Inquiry, v.16, n.5, p. 342-348, 2010.

JUELSKJAER, M. Gendered subjectivities of spacetimematter. Gender and Education, v. 25, n.6, p. $754-$ 768, 2013.

KAWASAKI, C.S. et al. A pesquisa em educação ambiental nos EPEAs (2001-2007): natureza dos trabalhos, contextos educacionais e focos temáticos. Pesquisa em Educação Ambiental, v.4, n.2, p.147$163,2009$.

KIRBY, V. Quantum anthropologies: Life at large. Durhan: Duke University Press, 2011.

KORO-LJUNGBERG, M. Reconceptualizing qualitative research: Methodologies without methodology. Los Angeles: Sage, 2016.

KORO-LJUNGBERG, M., \& MAZZEI, L. Problematizing methodological simplicity in qualitative research: Editors' introduction. Qualitative Inquiry, v. 18, n.9, p. 728-731, 2012.

LATHER, P. Paradigm proliferation as a good thing to think with: Teaching research in education as a wild profusion. International Journal of Qualitative Studies in Education, v. 19, n.1, p.35-58, 2006.

LATHER, P. Getting lost: Social science and/as philosophy. Educational Studies, v. 45, n.4, p. 342-357, 2007.

LENZ TAGUCHI, H. Going beyond the theory/practice divide in early childhood education: Introducing an intra-activity pedagogy. London and New York: Routledge, 2010. 
LENZ TAGUCHI, H. Images of thinking in feminist materialisms: Ontological divergences and the production of researcher subjectivities. International Journal of Qualitative Studies in Education, v. 26, $\mathrm{n}$. 6, p. 706-716, 2013.

LEWIS, T. Studying the educational logic of Patti Lather's getting lost. Qualitative Inquiry, v. 23, n.4, p. 300-308, 2017.

LOUREIRO, C. F. B. Trajetória e Fundamentos da Educação Ambiental. 2ed. São Paulo: Cortez, 2006. $150 \mathrm{p}$.

MACLURE, M. Qualitative inquiry: Where are the ruins? Qualitative Inquiry, v. 17, n. 10, p. 997-1005, 2011.

MAZZEI, L. Materialist mappings of knowing in being: Researchers constituted in the production of knowledge. Gender and Education, v. 25, n.6, p. 776-785, 2013.

MCCOY, K. Toward a methodology of encounters: Opening to complexity in qualitative research. Qualitative Inquiry, v. 18, n.9, p. 762-772, 2012.

OLIVEIRA, H.T. Popular education and environmental education in Latin America: converging path and aspirations. In: González-Gaudiano, E. \& Peters, M. Environmental education: identity, politics and citizenship. Amsterdam: Sense Publishers, 2008, p. 219-230.

PLUMWOOD, V. A review of Deborah Bird Rose's Reports from a Wild country: Ethics of decolonization. Australian Humanities Review, v. 42, p. 1-4, 2007.

SAUVÉ, L. Environmental Education Between Modernity and Postmodernity: Searching for an Integrating Educational Framework. Canadian Journal of Environmental Education, 4, Summer, p.9-35, $1999 b$.

SHILLING, C. Changing bodies. London: Sage, 2008.

SOMERVILLE, M. The post-human I Encountering 'data' in new materialism. International Journal of Qualitative Studies in Education, v. 29, n.9, p.1161-1172, 2016.

ST. PIERRE, E. Circling the text: Nomadic writing practices. In DENZIN, N.; LINCOLN, Y. (Eds.), The qualitative inquiry reader. Thousand Oaks, CA: Sage, 2002.

ST. PIERRE, E. Post qualitative research: The critique and coming after. In DENZIN, N.; LINCOLN, Y. (Eds.), Sage handbook of qualitative inquiry ( $4^{\text {th }}$ ed.), p. 611-635), Los Angeles: Sage, 2011.

ST. PIERRE, E.; PILLOW, W. (Eds.) Working the ruins: Feminist poststructural theory and methods in education. London: Routledge, 2000.

TAYLOR, C.; IVINSON, G. Editorial: Material feminisms: New directions for education. Gender and Education, v. 25, n. 6, p. 665-670, 2013.

THRIFT, N. Intensities of feeling: Towards a spatial politics of affect. Geografiska Annaler, Series B: Human Geography, n. 86, p. 57-78, 2004. 
TUANA, N. Viscous porosity: Witnessing Katrina. In ALAIMO, S.; HEKMAN, S. (Eds.), Material feminisms (pp. 188-213). Bloomington: Indiana University Press, 2008. 